\title{
Radicalisation in South Asia: Left, Right and Secular
}

\section{Suba Chandran}

\section{Introduction}

South Asia, the region on the Indian subcontinent, which reaches from Afghanistan in the west to Bangladesh in the east, and from Nepal in the north to Sri Lanka in the south, has gained the image of a home to religious fanatics. Islamist groups in Pakistan and Afghanistan in particular, but also more recently the rise of Hindu nationalists in India and Buddhist radicals in Sri Lanka, have contributed to the notion that violence in the region is motivated by religion. This image, furthered by the focus of terrorism research during the post-9/11 period, which particularly looked at religious radicalisation in the region, was reinforced by the recent Islamist terrorist attacks in Sri Lanka in April 2019. Violence in South Asia, however, is not solely a religious phenomenon.

Already before 9/11, large scale violence was perpetrated by left-wing extremists, like the Janatha Vimukthi Peramuna (JVP) in Sri Lanka in the 1970s or the Maoists in Nepal during the late 1990s, led by the Communist Party of Nepal (Maoist). Similarly, caste violence has shaped the post-independence history of the region, not only, but particularly in India. Today, organised violence against women has gained in prominence in the region, too. Thus, to think of South Asian violence only in terms of religion neglects the diversity of ideological and ideational backgrounds to violent actions.

This paper seeks to provide an overview of different cases of violence in South Asia. The paper argues that the range of phenomena is wide and diverse, but that what is common to the collective actors behind the violence is their usage of violence as a means towards a political or societal end. The paper will show that although there are diverse factors driving individuals to join or support violent activities, the underlying rationale is the political and/or societal endgame. Moreover, it is argued that the reasons for violence are multi-layered and cannot be understood by focusing on one driver only. Violence here is considered a tool implemented by an agent who aims at undermining the status quo and in order to impose a new order, 
irrespective of what ideological or religious background this political aim have.

\section{Left-Wing Violence in South Asia}

Three of the more prominent cases, in which left-wing groups are responsible for the perpetration of large scale violence in South Asia, are the Indian Naxalites, Nepali Maoists and Sri Lanka's Janatha Vimukthi Peramuna (JVP). In these cases, the groups aimed to overthrow the state violently by revolution, and to create a new state and society based on their respective understanding of them.

In India, left-wing extremism, referred to as the "Naxal movement" developed in phases since the country's independence (Banerjee 2008; Mukherji 2012; Raghavan 2011; Singh 2016). The Naxal violence has emerged in its first major phase in West Bengal, with "Naxalbari" as the core of its activities, from which it received the name Naxalites (Banerjee 2002:2115-16). In a second phase, the violent movement extended its reach to Andra Pradesh, Bihar and Jharkhand; and in a third phase, which is still continuing, the movement expanded and concentrated in primarily two Indian States, Orissa and Chhattisgarh (Bhatia 2005). For their "peoples war", the Naxalites build on Marxist slogans and primarily mobilise educated youths from the urban areas. However, its attraction not only derives from the Marxist ideology. The movement was able to draw on local issues to gain support from individuals other than the educated urban youths. As such, it drew on slogans of caste oppression in Bihar and Jharkhand, aiming to involve members of the Dalit community, and took up concerns of tribal communities in Orissa and Chhattisgarh (Bhatia 2005). The endgame of the Naxalites in each state, however, was nothing less than the fundamental transformation of state and society.

The aim to fundamentally transform state and society along the lines of Marxism was not limited to South Asia's territorially and population-wise largest state, India. In India's southern neighbour-state, Sri Lanka, the influence of Marxist ideas about the change of society and economy by revolutionary means, too, took its toll. The Janatha Vimukthi Peramuna (JVP) thereby formed the forefront of left-wing violence. The large scale leftwing violence perpetrated by the JVP and its supporters took place mainly in two phases, and manifested in two insurgencies of which the first started in 1971 and the second took place in 1987-89 (Venugopal 2010). According to Matthews, the founder of the JVP, Rohana Wijeweera "espoused a curious mixture of Marxism and Sihalese ethnic chauvinism" 
(1989a:312). For Matthews, "the JVP's deepest motive was to seize power by any means, even if it meant playing on the misguided ethnic loyalties of the Sinhalese" (ibid.). For Moore, the "means the JVP used in pursuit of state power were shaped by and adapted to the environment - the economic, educational and occupational structures, demography and human geography - of the Sinhalese areas of Sri Lanka to which the JVP was confined" (1993:594). The JVP-led violence was only ended by uncompromising violence applied by the Sri Lankan state.

Also to India's north, in Nepal, left-wing violence was applied as means towards the Maoists' endgame of overthrowing the monarchy and Nepali state. The aim here was creating a socialist republic. In Nepal, left-wing violence was largely perpetrated during the late 1990s and the early 2000 s by the Communist Party of Nepal (Maoist), popularly referred to as the Nepali Maoists (Crisis Group 2005). The Maoists' means of changing the regime was an armed struggle, referred to as 'People's War'. According to Verma and Navlakha, "In Maoist understanding, People's War is 80 per cent politics and 20 per cent warfare. The decisive factor in a war of this genre [are] not guns but the mobilization of people for seizing power through protracted war" (2007:1839). After fighting the Nepal military for a decade, the Maoists signed a peace agreement in 2008 with the government of Nepal and agreed to take part in the electoral politics. Subsequently, Nepal's Maoists came overboard and took part in the elections. Finally, in the 2008 elections or the National Constituent Assembly the party won around 38 per cent of the seats and formed the government. While the Maoists' violence has resulted in the transformation of the state, it has not brought about the society claimed to have been envisioned.

Despite these violent campaigns with a clear Marxist or Maoist ideology, other violent movements in the region have drawn and continue to draw on Marxism, despite a stated and clearly proclaimed ethnically grounded agenda. This has been the case with the Liberation Tigers of Tamil Eelam in Sri Lanka, but also with the Baloch insurgency during the 1960s-70s in Pakistan. Personal networks and relations have furthered the ideological relation to the left-wing globally. Especially the Marri tribes of Balochistan are considered to have been close to Moscow. The chief of the Marri tribe, Nawab Khair Baksh Marri, ${ }^{1}$ for example, took refuge in Kabul in 1979 and also his sons were sent to Moscow for education (Tahir 2008).

1 According to Tahir (2008"), "Khair Bakhsh Marri remains committed to an armed struggle for no less than full independence for Balochistan despite losing dozens of 


\section{Strategic Violence against Women in South Asia}

While domestic violence against women is neither a South Asian particularity, nor a new phenomenon but rather can be traced back for centuries, one finds that violence against women currently has reached a new political dimension. Political and societal support for violence against women as means to retain a patriarchal order can be found throughout South Asian societies. Most prominently, however, India and Pakistan serve as cases in point.

The local support for the brutal killings or physical abuse of women in the name of a caste or religion in Pakistan and India thereby not only cuts across provinces, but also religious or caste identities.

While some of the stories of the killing of women in this context have hit the news from Punjab in Pakistan to Tamil Nadu in India, many have never been reported. And yet, many examples can be given. Qandeel Baloch, an outspoken young model, was killed by her brother for bringing a bad reputation to the family in Multan in Pakistan. Saba Qaiser in Gujranwala in Pakistan was shot by her father, stuffed in a bag and dropped into a river, for marrying a person of her own choice. Muktaran Mai in Meerawala, Pakistan, was gang-raped on the orders of a local panchayat, as she stood up and spoke against the elders who wanted to bury the case of her brother getting sodomised.

While the above cases may be considered as individual crimes, what makes them significant in the context of this essay is the larger societal response to these killings. Many people in Pakistan supported the family, who killed Qandeel Baloch, for dishonouring the family values. ${ }^{2}$ Many of the victims, should they survive are forced to forgive the perpetrators of violence against them. Even in the brutal case of Saba Qaiser - to recall, she was shot, stuffed in a bag and thrown into a river by her own father - Qaiser was forced by the rest of her family to forgive her father to prevent a formal case against him. Despite the wide attention this case got, among others due to the film that covered the story, the societal response was not the sympathy for the female victim, but the rejection of the treatment of the issue. When the documentary titled "A Girl in the River: The Price of Forgiveness" on Saba Qaiser's case, directed by Sharmeen Obaid-Chinoy, won an Oscar, a section of the society in Pakistan went after the director

followers and relatives, most recently his son Balach Marri, who reportedly led a rebel group of the Baloch Liberation Army (BLA)".

2 Shamsi. BBC, 16 July 2016. 
for creating a bad name for the country. While responding to a question in the US on the crime against Muktaran Mai - a gang-rape ordered by a local panchayat - Pervez Musharraf, the then President of Pakistan said: "You must understand the environment in Pakistan...This has become a moneymaking concern. A lot of people say if you want to go abroad and get a visa for Canada or citizenship and be a millionaire, get yourself raped". ${ }^{3}$ Even more, Muktaran was prevented from visiting the US. The government thought it would bring a bad reputation to Pakistan, and kidnapped her. ${ }^{4}$

The issue in the context of this chapter is less the individual decision to kill a female family member. It is the collective reaction ranging from society to the state to tolerate, accept or even support and promote the violence against women, who do not conform to the societal expectations for them. The question is thus not only why families kill their members, but even more, why a section within the rest of the immediate society whether in the form of jirga or caste or religious groups - support the actions of these individuals and families. Looking at many of the responses and public statements in this regard, the answer to the question might be found in the intention to retain or (re-)create an 'ideal' society and, most notably, to put women in their 'right' place therein.

\section{Religion and Violence in South Asia}

Despite the diversity of violence, religious violence is a prominent feature of the politics in South Asia. However, not only purely religious issues promote the usage of violence, but also economic aims of individuals involved.

Haqqani (2006") points out that "religious, political parties have been a part of Pakistan's political scene since its inception. As the Pakistani State increasingly adopted an Islamic identity, sectarian differences and theological arguments led to the formation of sectarian political movements. The slogan 'Islam in Danger' was widely used during the campaign for Pakistan's creation, and it remained a powerful rallying cry for religion-based politics. Even secular civilian and military leaders found it expedient to argue, from time to time, that the nation must mobilize to fend off threats to Islam or to Pakistan's Islamic ideology".

3 Kristof. New York Times, 25 January 2020.

4 Ibid. 
This phenomenon in Pakistan manifested itself soon after independence not only in attacks on religious minorities, but also on those members of the Muslim community, not considered to be true Muslims. The anti-Ahmadi riots in the early 1950s are but one example. Though the Ahmadiya community considers itself as Muslim, the majority Sunni population rejects this claim. On this basis, the first major communal riot in independent Pakistan took place in 1953 against the Ahmadiya community, which became the target of these riots, that took place primarily in Lahore. Even a constitutional amendment passed in 1974 under Zulfikar Ali Bhutto considers the Ahmadiya as non-Muslims (Khan 2015).

Next to sectarian differences and claims of exclusivity, drivers to join violent groups claiming religious causes, however, include also economic ones. In the Jhang district of Punjab in Pakistan, the feudal lords of the region were Shias, whereas the majority of the peasants were Sunnis. The oppressive relationship between the feudal lords and peasants - which is economic in nature - assumed a religious identity for standing, the overcoming of which furthered Sunni violence against the Shia feudal lords. According to Ali, "The sectarian differences notwithstanding, the socio-political context of Jhang was such that the only way to break the dominance of the Shia feudal lords was to play on anti-Shia sentiment. To confront feudalism directly was next to impossible, in view of the fact that the majority of the population took it as something natural, about which they could not do anything. On the other hand, it was easier to mobilize them in the name of Islam, which had always been very close to their heart, even for those who were otherwise not very religious" (Ali 1999*).

Similarly, in the Coimbatore district in Tamil Nadu in India, one could see an economic motivation behind religious radicalisation. One of the big cities in Tamil Nadu (and in South India), Coimbatore has been known for its cosmopolitan nature, and was frequently referred to as the business city. During recent years, there has been evidence of radicalisation - of both the communities - Hindu and Muslim. According to Rajamohan $(2006$ "), "Economic rivalry between Hindu and Muslim traders is another major reason for the growth of fundamentalist organizations in Tamil Nadu. Since 1991, Coimbatore, a city with a substantial high-tech industrial infrastructure, has seen a translation of economic competition into fundamentalist confrontation. The business community uses these hardliners for their own economic and political benefits. It is much more prevalent in the small scale business enterprises which are active in the common Bazaars. For instance, the considerable textile industry in the city is organized along communal lines, and there is little cooperation, collaboration or interdependence between Hindu and Muslim textile traders”. 
As such violence in the name of religion appears, at times, to feature economic interests. Local economic rivalry gets exploited politically by right-wing groups on both sides of the religious divide. The presence of right-wing groups then in turn gets exploited by the businessmen - to either target the other, or to get protected by the former. Rajamohan refers to a police account and writes "when the Hindu Munnani posed a threat to their businesses, Muslim businessmen nurtured Basha, who began his career as a footpath trader in the Ukkadam and Oppanakkara areas. When the sequence of stabbings and counter-stabbings intensified, youth on either side of the divide joined the Hindu Munnani or Al-Ummah, leading to increasing communal polarization" (Rajamohan 2006*).

However, is notable that economic grievances, like unemployment or lack of education, or economic interests can neither be seen as the major driver of joining a violent group or movement.

The attackers of the Easter Sunday attacks on 21 April 2019 in Colombo have been identified and their background well analysed. Three hotels and churches in Colombo were targeted by suicide bombers on 21 April 2019, when the city was celebrating the Easter Sunday. More than 250 people were killed during these multiple attacks on that day, carried out by the members of a radical group - the National Thowheeth Jamat (Amarasingam 2019). An initial report of the New York Times (2019) quoting the officials mentioned the following: "The suicide bombers who struck churches and hotels were all well-educated, middle-class Sri Lankans”. 5 Two of the suicide bombers, who were a part of the nine members team that perpetrated the attacks, came from a wealthy family. ${ }^{6}$ One report referred them as the "millionaire brothers". 7 According to Srinivasan, "Ishana Exports is a nearly three decade-old spice export company. Its founder Y.M. Ibrahim is widely known as a millionaire with modest beginnings, and an ever-ready philanthropist. He has friends of all political hues, and they all respect him. In natural course, his sons would have inherited his business, fortune, and possibly all that goodwill. Instead, they chose to become suicide bombers". 8

A similar trend manifests itself in an earlier attack in Dhaka in July 2016. On 1 July 2016, six young militants, armed with crude bombs and guns, took hostage of a bakery in Dhaka. It ended up in killing 29 people;

5 New York Times, 24 April 2019.

6 Gettleman et al. New York Times, 27 April 2019.

7 Srinivasan. The Hindu, 25 May 2019.

8 Ibid. 
20 were hostages (18 foreigners from Japan, Italy and the US, and two from Bangladesh), two were police officers, and two were from the bakery. ${ }^{9}$ According to a New York Times report on the identity of the attackers, "the men, all in their late teens or early 20s, were products of Bangladesh's elite, several having attended one of the country's top English-medium private schools as well as universities both in the country and abroad". ${ }^{10}$ The report also quotes a local source claiming: "That's what we're absolutely riveted by... That these kids from very affluent families with no material want can still be turned to this kind of ideology, motivated not just to the point of killing but also want to be killed". ${ }^{11}$

\section{The Glocal and Violence}

While political aims underlying violence can arise from the local cultural, economic and religious conditions, external ideologies and ideas promoted by international radical groups need to be considered as drivers of radicalisation in South Asia. Radical Salafi-Wahabi ideologies as well as the ideas promoted by organisations such as the al Qaeda and ISIS, are considered as such $^{12}$ - but also Marxist or Maoist ideologies are a case in point. And yet, the mere introduction of these ideas does not suffice to translate them into political aims in the South Asian context for whose achievement individuals are willing to perpetrate violence.

The process could be explained through franchise and franchisee model (Chandran 2011). Like any international franchise would want regional franchisees, the strategic aims of transnational organisations such as IS or al Qaeda seek to expand their area of influence. Regional political interests, in turn, would find global symbols attractive and seek to become part of an international chain or network. As such, one could quickly identify the interests of the Middle Eastern organisations and states in exporting SalafiWahabi ideology, not only into South Asia, but also into Southeast and Central Asia, and even beyond.

At the same time, local groups and organisations are willing to join global movements to gain from prestige, knowledge, resources and support. For example, a group of the Tehrik-e-Taliban Pakistan (TTP) that was

9 New York Times, 3 July 2016.

10 Manik and Anand. New York Times, 3 July 2016.

11 Ibid.

12 Ibid. 
fighting the State in Pakistan and which owed its allegiance to Mullah Omar of the Taliban, in January 2015, announced its allegiance to the Islamic State. ${ }^{13}$ Earlier in 2014, according to a news report, "six top commanders of the outlawed Tehreek-i-Taliban Pakistan, including spokesman Shahidullah Shahid" announced their allegiance to Abu Bakr al Baghdadi of the Islamic State. ${ }^{14}$ The report referred to Shahhid saying, "I am confirming my allegiance to Amirul Momineen Abu Bakr al Baghdadi and would abide by all his decisions, whatever is the order, and whatsoever the circumstances, I shall be loyal to him and obey his orders". ${ }^{15}$

\section{Violence Itself a Driver of Violence}

The role of minority-majority relations in the escalation of contention into violence is frequently disputed. Thereby it is difficult to argue for the fault of the one about the other, as violence is frequently the result of escalation.

In India, the demolition of the Babri Masjid took place in 1992; the demolition was led by right-wing Hindu militant organisations, led by the Vishwa Hindu Parishad, a radical right-wing group. Lochtefeld pointed out how the demolition triggered a wave of communal violence in India (1994:587-602).

In Sri Lanka, the majoritarian violence against the Tamils started during the 1980 s itself. July 1983 witnessed a significant riot across the country against the Sri Lankan Tamils. Later in 1987, there were riots again, primarily in the eastern province of Trincomalee. Tamil and Sinhala violence furthered the motivation to join violent movements.

\section{Conclusion: The Endgame behind Violence in South Asia}

The paper has presented an overview over different violent groups and movements in South Asia. It has shown that the aiming at changing or preserving a social or political order matters in all cases, suggesting violence to be a means towards an end. It was shown that the formation of political aims is not limited to religious backgrounds and that individual's reasons for participating in violence or violent organisations may vary.

13 Dawn, 11 January 2015.

14 Dawn, 14 October 2014.

15 Ibid. 


\section{References}

* in the text denotes a non-newspaper online source for a given quote, for which no page numbers can be provided.

Ali, Mukhtar Ahmad. 1999. "Sectarian Conflict in Pakistan: A Case Study of Jhang”. RCSS Policy Studies, 9, Colombo. (https://www.rcss.org/publication/poli cy_paper/RCSS\%20Policy\%20Studies\%209.pdf). Accessed 17 April 2020.

Amarasingam, Amarnath. 2019. "Terrorism on the Teardrop Island: Understanding the Easter 2019 Attacks in Sri Lanka”. CTC Sentinel, 12 (5). (https://ctc.usma.edu /terrorism-teardrop-island-understanding-easter-2019-attacks-sri-lanka/). Accessed 15 January 2020.

Banerjee, Sumanta. 2002. "Naxalbari: Between Past and Future". Economic and Political Weekly, 37 (22): 2115-16.

Banerjee, Sumanta. 2008. India's Simmering Revolution: The Naxalite Uprising. New Delhi: Zed Books.

Bhatia, Bela. 2005. "The Naxalite Movement in Central Bihar". Economic and Political Weekly, 40 (15): 1536-49.

Chandran, D Suba. 2011. “Ten Years After: 'Terror Franchisees' as an Evolving Phenomenon”. IPCS, 26 September 2011. (http://www.ipcs.org/comm_select.php?ar ticleNo=3463). Accessed 24 December 2019.

Crisis Group. 2005. "Nepal's Maoists: Their Aims, Structure and Strategy”. Crisis Group, Report 104. (https://www.crisisgroup.org/asia/south-asia/nepal/nepals-ma oists-their-aims-structure-and-strategy). Accessed 15 January 2020.

Dawn. 2014. "Six top TTP commanders announce allegiance to Islamic State's Baghdadi”. Dawn, 14 October 2014. (https://www.dawn.com/news/1137908). Accessed 12 April 2020.

Dawn. 2015. "Ex-TTP members pledge allegiance to Islamic State”. 11 January 2015. (https://www.dawn.com/news/1156376). Accessed 12 April 2020.

Gettleman, Jeffrey; Schultz, Kai; Mashal, Mujib and Goldman, Russell. 2019. "Two Super-Rich Families Ended Up on Opposite Sides of Easter Attacks”. New York Times, 27 April 2019. (https://www.nytimes.com/2019/04/27/world/asia/sri-lanka -attacks-wealthy.html). Accessed 4 February 2020.

Haqqani, Husain. 2006. "Weeding Out the Heretics: Sectarianism in Pakistan". Hudson. (https://www.hudson.org/research/9769-weeding-out-the-heretics-sectari anism-in-pakistan). Accessed 12 April 2020.

Khan, Adil Hussain. 2015. From Sufism to Abmadiyya: A Muslim Minority Movement in South Asia. Indiana: Indiana University Press.

Kristof, Nicholas D. 2005. "Lining Up to Be Raped?”. New York Times, 20 September 2005. (https://www.nytimes.com/2005/09/20/opinion/lining-up-to-be-raped. html). Accessed 25 January 2020.

Lochtefeld, James G. 1994. "The Vishva Hindu Parishad and the Roots of Hindu Militancy". Journal of the American Academy of Religion, 62 (2): 587-602. 
Manik, Julfikar Ali and Anand, Geeta. 2016. "After Slaughter, Bangladesh Reels at Revelations About Attackers”. New York Times, 3 July 2016. (https://www.nytim es.com/2016/07/04/world/asia/bangladesh-dhaka-terrorism.html). Accessed 5 February 2020.

Matthews, Bruce. 1989a. "The Janatha Vimukthi Peramuna and the Politics of the Underground in Sri Lanka". The Round Table, 78.

Matthews, Bruce. 1989b. "Sri Lanka in 1989: Peril and Good Luck". Asian Survey, 30 (2): 144-149.

Moore, Mick. 1993. "Thoroughly Modern Revolutionaries: The JVP in Sri Lanka”. Modern Asian Studies, 27 (3).

Mukherji, Nirmalangshu. 2012. The Maoists in India: Tribals Under Siege. New Delhi: Pluto Press.

New York Times. 2016. "Dhaka Victims Were a Diverse Group of Global Citizens”. 3 July 2016. (https://www.nytimes.com/2016/07/04/world/asia/dhaka-victims-we re-a-diverse-group-of-global-citizens.html). Accessed 12 April 2020.

New York Times. 2019. “Sri Lanka Attacks: What We Know and Don't Know”. 24 April 2019. (https://www.nytimes.com/2019/04/24/world/asia/sri-lanka-easter-bo mbing-attacks.html). Accessed 12 April 2020.

New York Times. 2019. “Sri Lanka Attacks: What We Know and Don’t Know”. 24 April 2019. (https://www.nytimes.com/2019/04/24/world/asia/sri-lanka-easter-bo mbing-attacks.html). Accessed 3 February 2020.

Raghavan, V.R. 2011. The Naxal Threat: Causes, State Responses and Consequences. New Delhi: VIJ Books.

Rajamohan, P.G. 2006. "Tamil Nadu: The Rise of Islamist Fundamentalism”. Faultlines, 16. (https://www.satp.org/satporgtp/publication/faultlines/volume16/Articl e5.htm). Accessed 12 April 2020.

Shamsi, Amber Rahim. 2016. "Qandeel Baloch: How Her Murder Reflects a Divided Country”. BBC, 16 July 2016. (https://www.bbc.com/news/world-asia-368158 08). Accessed 25 January 2020.

Singh, Prakash. 2016. The Naxalite Movement in India. New Delhi: Rupa.

Srinivasan, Meera. 2019. "The Inside Story of the 9 Suicide Bombers Behind Sri Lanka's Savage Easter Attacks”. The Hindu, 25 May 2019. (https://www.thehindu .com/news/international/the-inside-story-of-the-9-suicide-bombers-behind-sri-lan kas-savage-easter-attacks/article27236216.ece/amp/). Accessed 29 March 2020.

Tahir, Muhammad Tahir. 2008. "Tribes and Rebels: The Players in the Balochistan Insurgency”. Terrorism Monitor, 6 (7). (https://jamestown.org/program/tribes-and -rebels-the-players-in-the-balochistan-insurgency). Accessed 29 March 2020.

Venugopal, Rajesh. 2010. "Sectarian Socialism: The Politics of Sri Lanka's Janatha Vimukthi Peramuna (JVP)”. Modern Asian Studies, 44 (3): 567-602.

Verma, Anand Swaroop and Navlakha, Gautam. 2007. "People's War in Nepal: Genesis and Development”. Economic and Political Weekly, 42 (20). 
